\title{
Climate repair through built environment: Decarbonising UK's building sector through energy efficiency and natural materials
}

\author{
Ramit Debnath, Ronita Bardhan, Darshil Shah, Antiopi Koronaki, Aurimas \\ Bukauskas, Anthony Colman, Ana Gatoo, Eduardo Wiegand, Yelda Gin, Michael \\ Ramage
}

Centre for Natural Material Innovation (CNMI) \& Sustainable Design Group (SDG)

Department of Architecture

University of Cambridge

1 Scroope Terrace

Cambridge CB2 1PX

cnmi.org.uk

\section{Introduction}

The Centre for Natural Material Innovation (CNMI) in the Department of Architecture at the University of Cambridge is a cross-disciplinary centre, bringing together people and research in plant sciences, biochemistry, chemistry, fluid dynamics, engineering, and architecture. Through innovative research and experimentation, we aim to transform the way we build to achieve zero carbon emissions. Our work enables the substitution of anthropogenic materials such as concrete and steel with nature-based, biogenic materials such as timber and bamboo, and replacement of structural carbon fibre and glass fibre with hemp and flax-based biocomposites. We collaborate with other leading research institutions globally, including in the USA, China, Australia, Uruguay and others.

The Centre for Natural Material Innovation is led by Dr Michael Ramage, who has been appointed as one of the expert advisers (Theme 2: The Environmental Footprint of the Built Environment) to help shape the Built Environment Summit.

The Sustainable Design Group (SDG), led by Dr Ronita Bardhan, in the Department of Architecture at the University of Cambridge is a transdisciplinary research group that looks at the built environment through the technical and social lens using data driven intelligence for effectively address the sustainability goals and policies. The group works in the niche sector of sustainable built environment to inform health and energy decisions in the wake of changing climate to respond to four United Nations Sustainable Development Goals (i)SDG7 - clean energy and just energy transition; (ii)SDG3 - health and well-being through design elements of built-environment; (iii) SDG11- sustainable residential communities and (iv) SDG5 - Gender mainstreaming through built-environment design. The data-driven methods couples architectural engineering, Al and machine learning with social sciences to provided built environment solutions for optimised urban forms, operational energy use, efficiency and associated health burdens. The group has successfully identified the parametric design 
elements that can render a built environment dysfunctional which in turn can significantly affect energy transition, health decisions, and gender mainstreaming especially in poverty. The outcomes of the research group informs demand-side design solutions which positively affects well-being, energy security, and gender equality while entailing fewer environmental risks.

The Sustainable Design Group has worked immensely in the energy use, transition and respiratory health in the affordable housing segment of the Global South. The group is currently working on (i) thermal infra-red telescopes for use in space which can measure the energy usage of any building on the planet. About one third of the total carbon emissions on earth are from heating or cooling buildings and the telescopes will identify bad practice and lead to action to improve energy efficiency ; (ii) Hybrid indoor office/ commercial space design to facilitate new normal of working; (iii) developing Al driven models to understanding association of energy transition and mortality in the domestic sector and (iv) Climate risks and mortality confounded through built environment. The group has currently contributed to the Green Recovery from COVID-19: A COP26 Universities Network Briefing; The MINE research network (funded by British Council, Newton Bhaba, BEIS, UK and Department of Biotechnology, Government of India) on Al and machine leaning approaches in built environment to respond to pandemics.

We are delighted that RIBA, in partnership with Architects Declare, have launched the Built Environment Summit, seeking evidence across various themes on climate action. In addition to providing evidence for this inquiry, the CNMI have previously submitted evidence ${ }^{1}$ to the UK House of Commons Environmental Audit Committee's inquiry into 'Sustainability of the Built Environment', and we are also working with Gonzalo Muñoz and Nigel Topping, highlevel climate champions for the COP-25 and COP-26 conferences, respectively, to support the UK's leadership in this area at the COP-26 conference.

CNMI is also working with the United Nations Global Alliance of Building Councils (GlobalABC), supporting in the area of green building code development around sustainable construction using nature-based solutions (NBS) such as engineered timber and bamboo. We are discussing with the FAO their analysis on world forest cover in 2050.

The CNMI will also be giving evidence to the Chilean Parliament's Future Challenges Commission regarding the greater adoption of timber in construction there as part of the "Forestry Future for a Sustainable Chile" strategy.

Here, the CNMI and SDG advocate for climate repair through the built environment by decarbonising UK's building sector through both improved energy efficiency of buildings and the use of nature-based solutions, such as engineered timber and natural insulating materials. The UK has the opportunity to lead by example at the upcoming United Nations COP-26 conference and beyond, as we implement the solutions in the coming years.

${ }^{1}$ https://committees.parliament.uk/writtenevidence/36175/pdf/ 


\section{Buildings-related emission profile of the UK}

The net territorial emissions in the UK in 2019 were estimated to be 458.8 million tonnes carbon dioxide equivalent $\left(\mathrm{MtCO}_{2} \mathrm{e}\right)$. Carbon dioxide made up around $80 \%$ of the 2019 total emissions profile (see Fig 1$)^{1}$. The UK has domestic targets for reducing greenhouse gas (GHG) emissions under the Climate Change Act 2008 (CCA $)^{2}$, that established a long-term legally binding framework to reduce emissions by at least 80\% below 1990/95 baselines by 2050 . This target was further expanded to $100 \%$ reduction in emissions (net-zero) by 2050 , following the IPCC's Special Report on Global Warming of $1.5^{\circ} \mathrm{C}$ and advice from the independent Committee on Climate Change in 20191,3.

\section{UK territorial greenhouse gas emissions, 1990-2019}
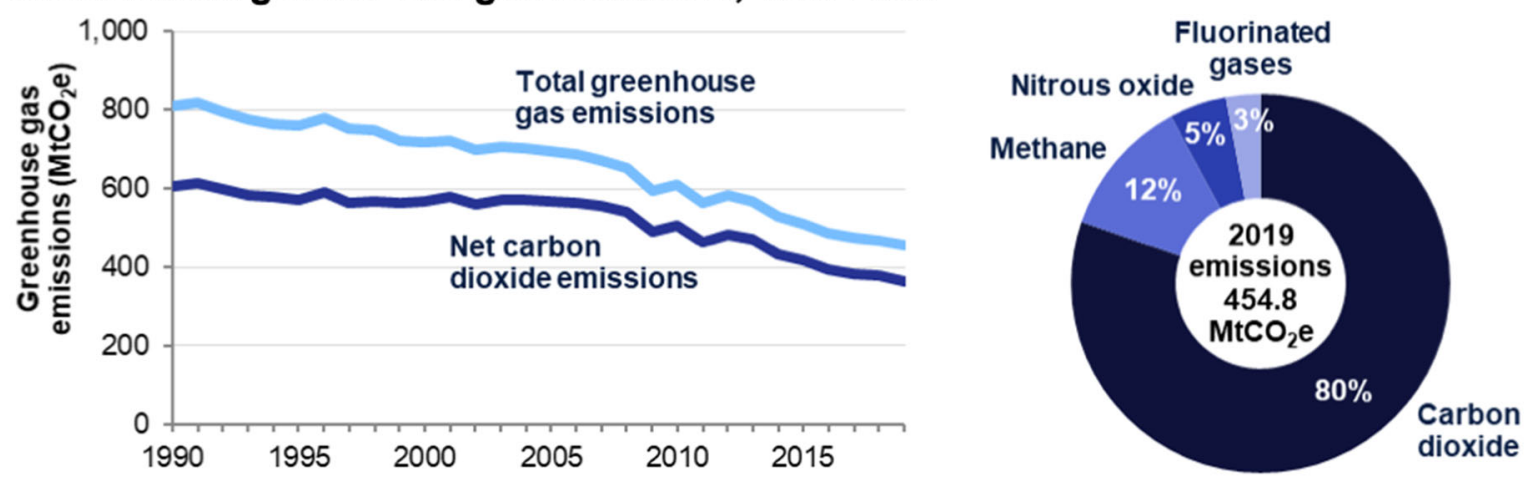

Fig 1. UK greenhouse gas emissions, 2019 (Source: BEIS, UK Government ${ }^{1}$ )

Emission profile by sector is illustrated in Fig 2. In 2019, $27 \%$ of net GHG emissions in the UK were estimated to be from the transport sector, $21 \%$ from energy supply, $17 \%$ from business, $15 \%$ from the residential sector and $10 \%$ from agriculture. Waste, management, industrial processes, the public sector and the land use, land use change and forestry (LULUCF) sector attributed to the remaining $10 \%{ }^{1}$.

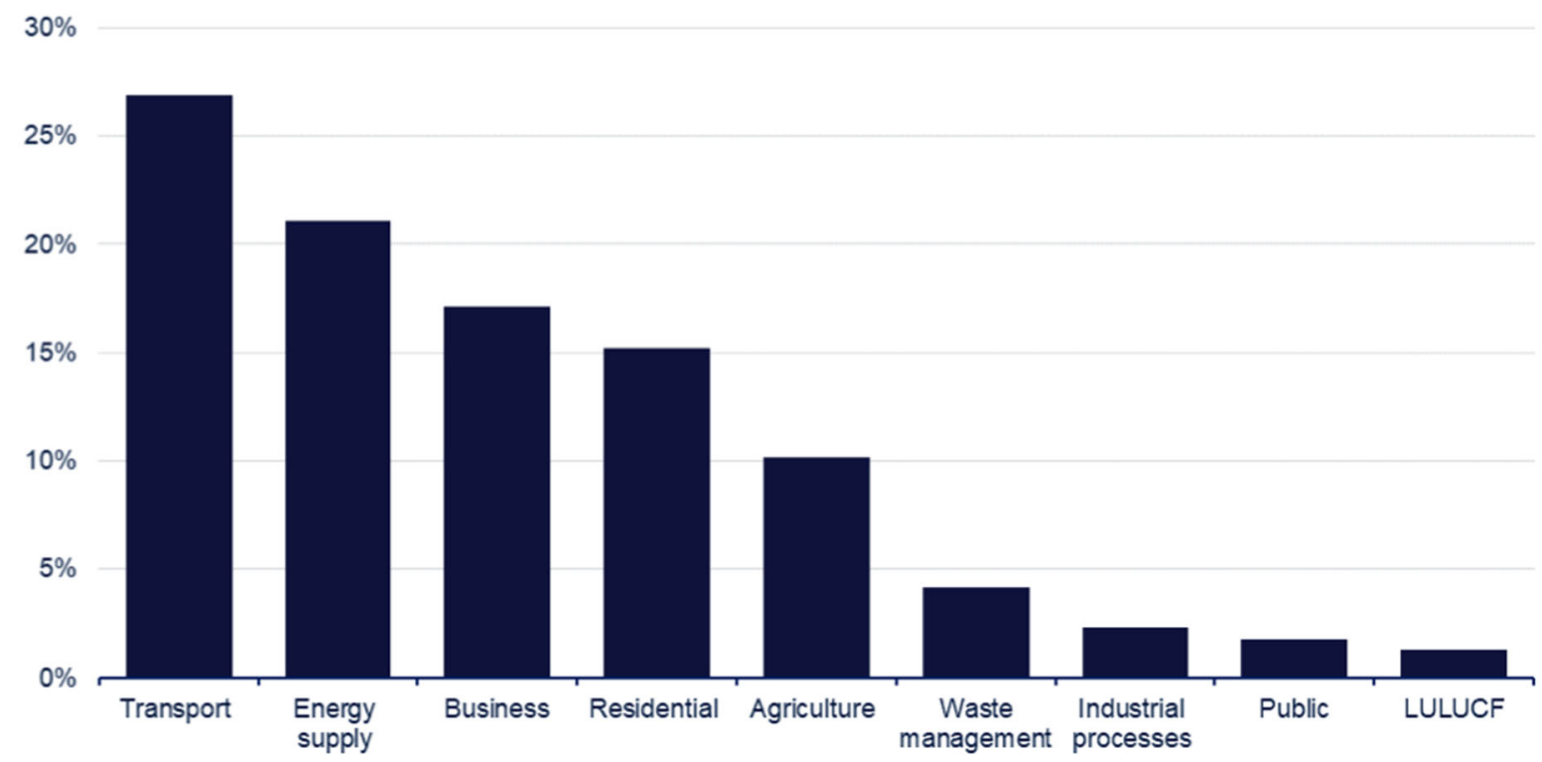

Fig 2. UK GHG emission profile by sector national statistics, 2019 (Source: BEIS, UK Government ${ }^{1}$ ) 
In 2019, the transport sector and the residential sector cumulatively contribute around $42 \%$ (192.6 $\mathrm{MtCO}_{2} \mathrm{e}$ ) of the UK's total carbon footprint (see Fig 2). UK Green Building Council's estimation showed that almost half of this emission was from energy used in buildings (e.g., plug loads and cooking) and infrastructure (e.g., roads and railways) ${ }^{4}$. However, it highlighted the lack of information on functional or 'in use' emissions in the building sector ${ }^{4}$.

Direct GHG emissions from buildings were $87 \mathrm{MtCO}_{2} \mathrm{e}$ in 2019, split between homes (77\%), commercial buildings (14\%) and public buildings (9\%). Direct emissions in buildings results primarily from the use of fossil fuels for heating. Around $74 \%$ of the UK's heating and hot water demand in buildings is met by natural gas, and $10 \%$ by petroleum, with smaller amounts of other fuels such as coal and biomass ${ }^{5,6}$ (see Fig 3). Direct emissions from buildings fell by 19\% from 1990 to 2015 and have remained at a similar level since. This downward trend largely reflect energy efficiency improvements in buildings ${ }^{5}$, better insulation rates and decarbonisation of the grid electricity ${ }^{4,7}$.

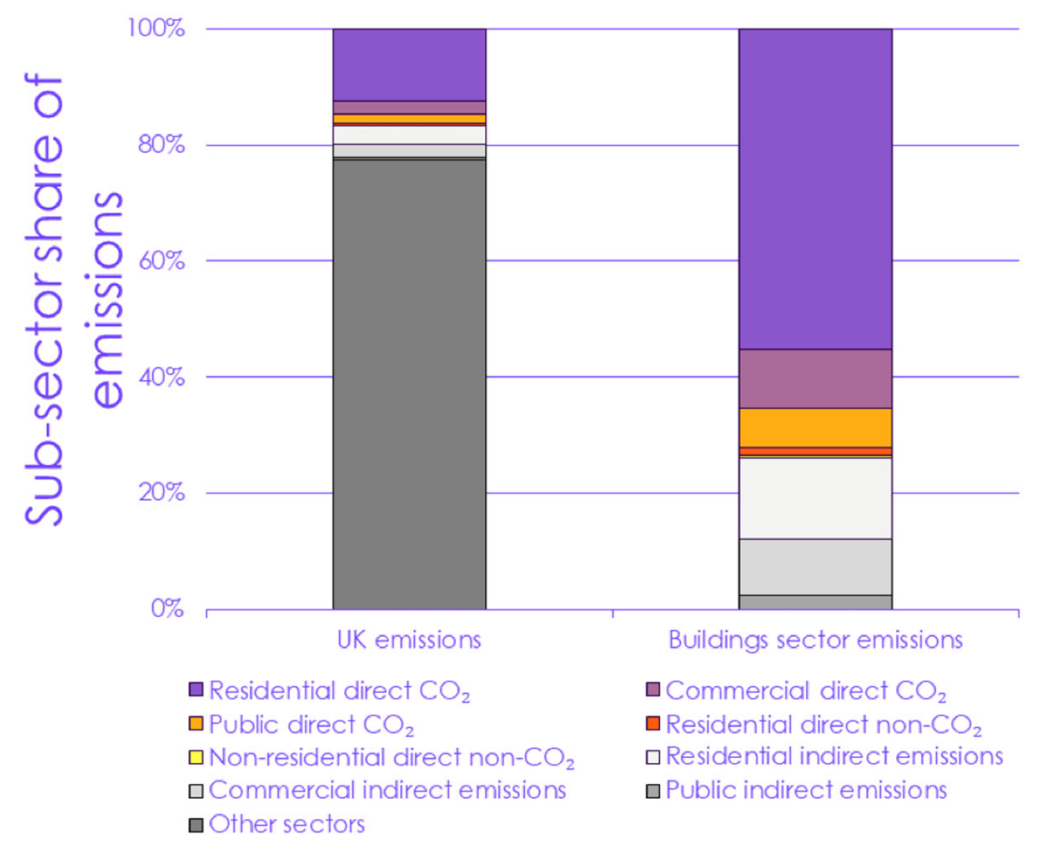

Fig 3. Breakdown of building sector GHG emissions, 2019 (Source: CCC ${ }^{5}$ )

In terms of indirect emissions, buildings are responsible for $59 \%$ of UK electricity consumption for its operation, contributing to a further $31 \mathrm{MtCO}_{2} \mathrm{e}$ in 2019. This operational energy consumption in buildings stems from appliances usage and lighting in home, cooling, catering and ICT equipment in non-residential buildings ${ }^{5,8}$. Additionally, around $1.4 \mathrm{MtCO}_{2} \mathrm{e}$ of methane and $0.8 \mathrm{MtCO}_{2} \mathrm{e}$ of nitrous oxide emissions were associated with buildings in $2019^{5}$.

The Committee on Climate Change (CCC) considers that the building and built environment is a difficult sector to decarbonise ${ }^{5}$. However, it holds tremendous potential for contributing to the net zero transition. ${ }^{5}$. It represents a large opportunity for mitigation of GHG emissions in the UK. The UK has an unusually old building stock and so retrofitting will play a key role in achieving net zero ${ }^{7}$. More investment in low carbon and efficiency measures is required to 
retrofit old building stocks as well as supporting the upcoming building stocks. Emission reductions in buildings can be achieved in two ways: (i) By reducing the operational emissions; and (ii) by ensuring low or zero embodied carbon across the life cycle of the building ${ }^{1,5,7,9}$.

\section{Reducing operational emissions through low-carbon technologies}

Existing evidence show that operational emissions can be minimised by reducing energy usage in buildings through energy efficiency measures such as retrofitting, insulation, double glazing, energy efficient appliances, behaviour change and switching away from fossil-fuel based heating systems ${ }^{5,9}$. UK Government's conducted a study in 2005 to scope the future of low-carbon technologies in improving energy efficiency and emissions reductions in the built environment ${ }^{10}$. Fig 4 illustrates the benefit score of each technology based on costeffectiveness of carbon reduction benefits ( $x$-axis) and potential economic benefit to the UK (y-axis). Technologies for lighting (OLEDs, LEDs), heating (Micro-CHP, intelligent monitoring), smart building management (BMS) and home networking systems, integrated widow design (glazing) and building integrated renewable systems (solar thermal) received high carbonbenefit score (see Fig 4).

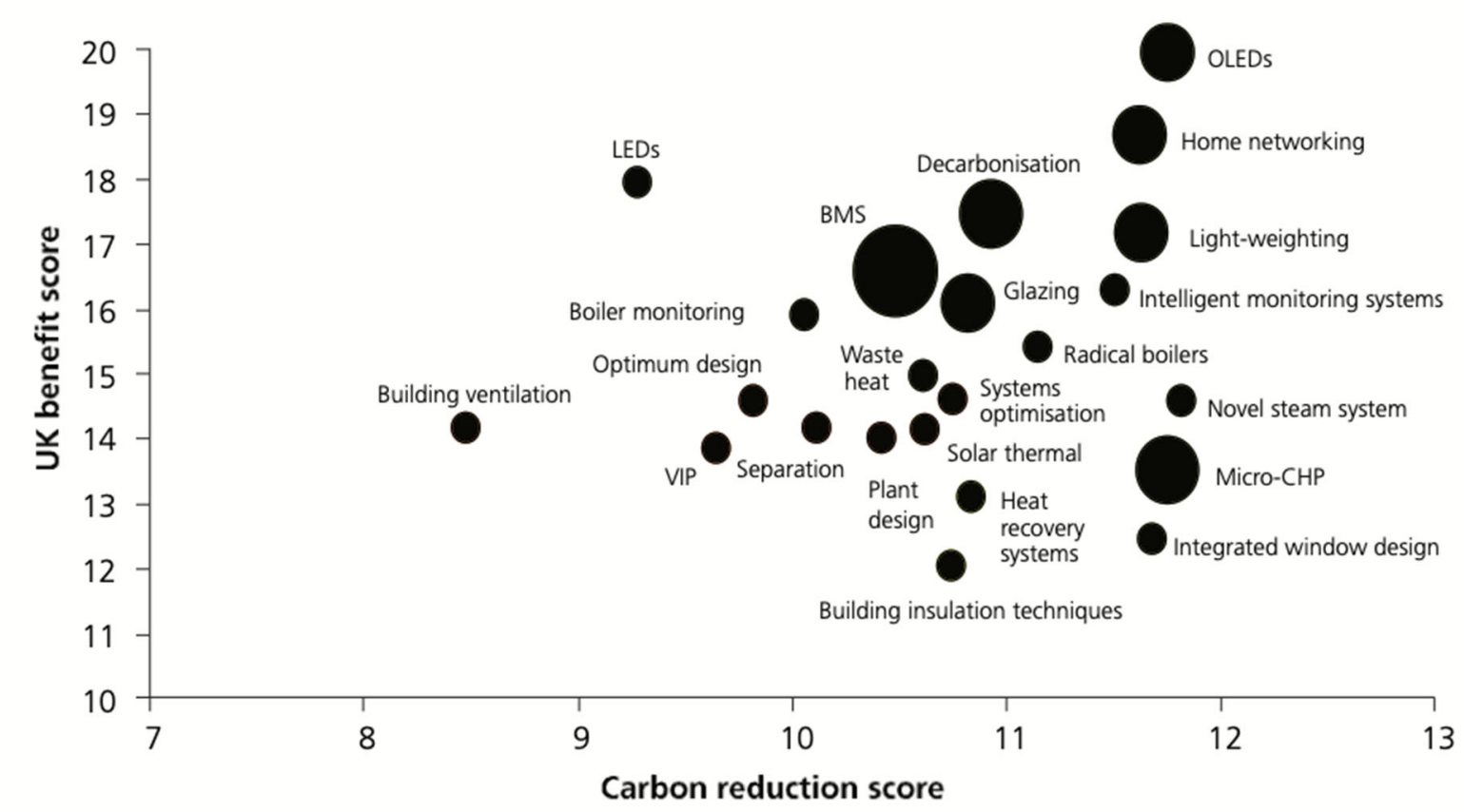

Fig 4. Energy efficient and low-carbon technologies. (Source: DEFRA, UK Government ${ }^{10}$ )

[Note: The size of the bubble indicates the calculated total potential carbon reduction associated with each technology (regardless of cost effectiveness or economic benefit)]

Existing evidence strongly supports that behaviour change holds significant opportunities to deliver emissions savings in the building sector ${ }^{11-15}$. A study commissioned by the UK Cabinet Office in 2011 investigated behavioural barriers to achieve energy efficiency in buildings ${ }^{14}$. It showed that emission reductions through behavioural change should consider people's tendency to 'discount the future', i.e., they may prefer a smaller reward today over a larger reward in the future. Energy efficiency improvements in buildings relates to the above fact 
that benefits are accrued over a long period of time, whereas the costs associated with them are immediate and sometimes large ${ }^{14}$. This study also found the importance of social norms in encouraging adoption of green behaviour. Similar, behavioural insights on energy efficiency suggested that individuals tend to go with the flow of pre-set options, or defaults often regardless of whether the pre-set options maximise our individual or collective wellbeing ${ }^{14,16,17}$.

The CCC also identified opportunities for behaviour change in domestic heating using smart hybrid heat pumps (HHP). Heating and hot water for UK homes make up 25\% of total UK energy use and $15 \%$ of GHG emissions ${ }^{5,11}$. Within UK homes, space heating and domestic hot water account for $79 \%$ of household energy requirements ${ }^{8}$. Near $100 \%$ decarbonisation of domestic heating is needed for achieving its net zero ambitions. However, emissions from domestic heating are not falling since 2015 , instead emissions rose by $1 \%$ in $2017^{18}$. Existing evidence suggests that the greatest potential for emissions reductions $\mathrm{s}$ is not through dayto-day behaviours in heat system usage but the uptake of low carbon heating systems and building refurbishment for improved thermal performance ${ }^{11,14}$. Besides, greater awareness of how to avoid wasting energy is needed as a behavioural public policy measures, e.g., better use of thermostats, flow temperature and hydraulic balancing ${ }^{11,19}$.

Decarbonising heat in older homes with poorer thermal performance is a much greater and more pressing challenge to the UK, especially when it is estimated that three-quarters of houses that will be in use in 2050 will have been built before $2010^{18}$. Smart HHP is expected to play an important role and recent evidence suggests there is a case for deployment at sake from $2020^{5,11}$. Retrofitting HHP to older homes can offer emission reduction benefits as consumers can retain their existing gas central heating system for backup heating that can ensure little risk of thermal comfort ${ }^{20}$. When combined with time-varying pricing of electricity, running costs can be low as well as offers flexibility to switch to gas boiler when electricity prices are high and extra heat is needed. In long-term, smart HHP could offer broader flexibility to incorporate more green gas or be adapted for hydrogen gas ${ }^{20-22}$. However, behavioural interventions to enable greater acceptance and demand from consumers for such low-carbon technologies remain critical for reducing operational emissions.

New builds will need to meet extremely ambitious standards of energy efficiency and low embodied carbon. The CCC and its Adaptation Committee's assessment showed that new build homes should have high levels of airtightness; more fresh air with mechanical ventilation and heat recovery, and passive cooling measures; triple glazed windows and external shading; low-carbon heating; water management and cooling through green roofs, reflective walls; enhanced flood resilience and resistance, and use of natural materials like timber in construction ${ }^{18}$. The existing homes should be retrofitted for avoiding heat loss through enhanced insulation and window glazing measures. Low-carbon heating with heat pumps or connections to district heat networks are critical for reducing operational emissions. Similarly, highly energy-efficient appliances $\left(A^{* *}\right.$ and $A^{* * *}$ rating) at a household level can cut emissions along with the adoption of highly water-efficient devices (like low-flow showers and taps) for reducing domestic electricity requirement. Larger green space coverage (e.g., garden and trees) can help reduce the risks and impacts of flooding and overheating ${ }^{5,18}$. 
A recent data on UK's commercial and business premise shows that there are more than 7000 spaces across England, Scotland, and Wales, currently owned by Local Authorities, had been empty and vacant for over 12 months. These vacant spaces has the potential to mitigate the gap of homelessness by generating over 19,500 residential units through the conversion of vacant office and retail space. The increased need of residential spaces due to the impact and repercussions of the Covid-19 pandemic and the shift to work from culture will increase demand for innovative house building and pioneering solutions for repurposing of existing buildings and housing stock. This opportunity of re-understanding built environment can act as climate repair.

The UK's commitment of zero carbon by 2050 can be achieved through effective builtenvironment re-design. With new forms of working and transitioning social norms to accommodate climate risks, indoor living will drastically change the operation energy use and associated health burdens. Innovative design and data can enable a just and efficient transition which can be attained through the tripartite policy changes

(i) In building design and regulation, the effect of policy control variables should be linked to urban overheating

(ii) In planning, socially inclusive decarbonisation variables (especially pertaining to gendered well-being, space, agency and energy use) should be incorporated.

(iii) In design innovative data from sources should be included

\section{Reducing embodied carbon emissions through natural materials}

The Global Status Report for Buildings and Construction (2019) by the International Energy Agency, identifies reduction of embodied energy and greenhouse gas (GHG) emissions as a priority for action towards a just net-zero transition ${ }^{23}$. It emphasises on the need of accountability for lifetime carbon of construction by replacing use of carbon intensive materials, such as concrete and steel, with sustainable alternatives like timber ${ }^{7}$. Fig 5 shows total embodied carbon by material type, and the embodied carbon attributable to UK carbon accounts vs. imported products where embodied carbon is accounted elsewhere (structural elements only). 


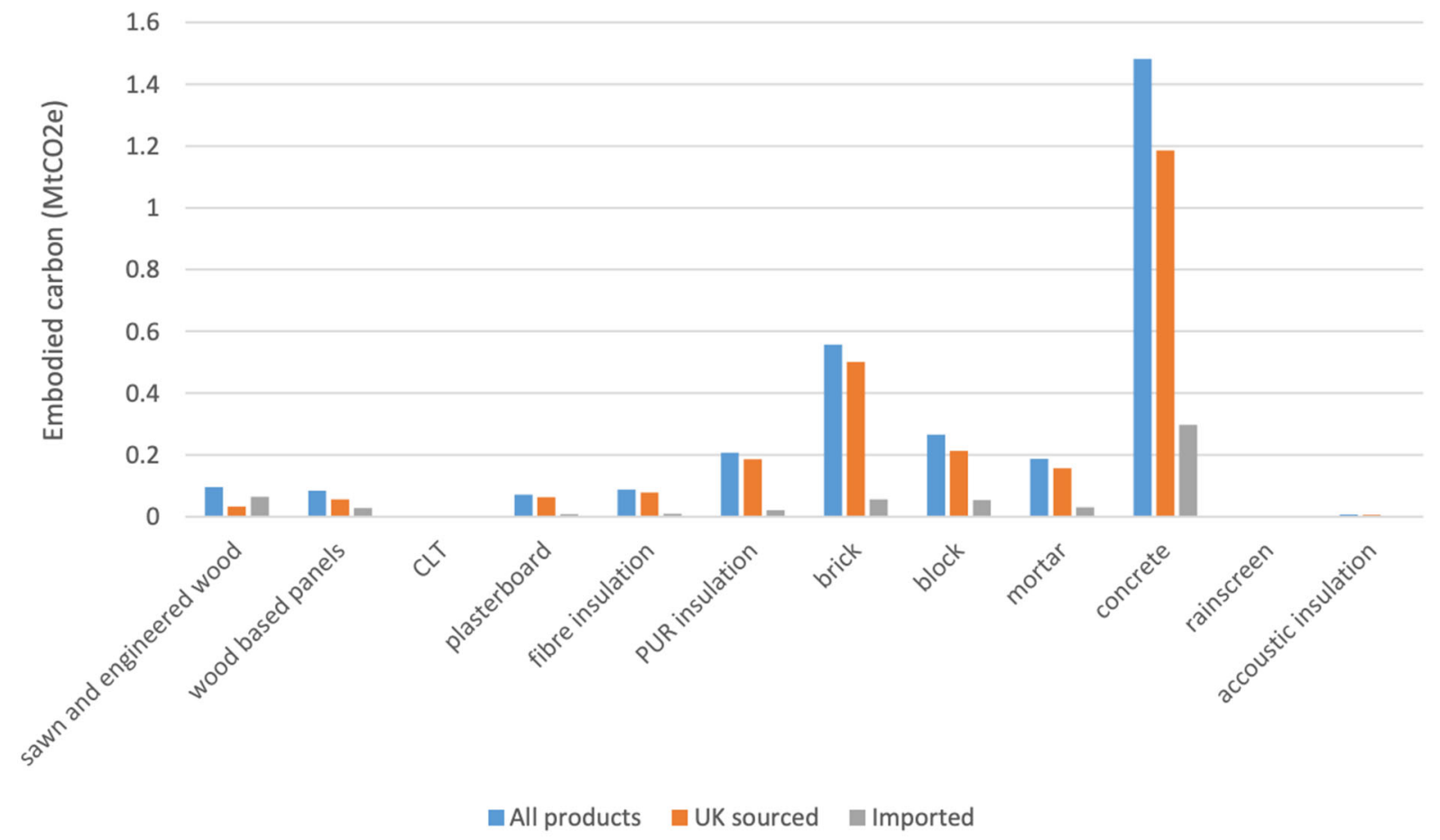

Fig 5. Embodied carbon of materials in UK construction industry, 2018 (Source: CCC $^{24}$ )

Studies have shown that engineered timber, such as glulam and cross-laminated timber (CLT), is increasingly recognized as a viable alternative, with examples of up to 14 stories already realized, 24 stories under construction, and even taller buildings planned around the globe ${ }^{25-}$ 27. Exiting evidence shows that timber frames have the lowest median value (at $~ 200$ $\mathrm{kgCO}_{2} \mathrm{e} / \mathrm{m}^{2}$ ) for embodied carbon compared to steal and concrete systems (at $~ 350-380$ $\mathrm{kgCO}_{2} \mathrm{e} / \mathrm{m}^{2}$ ), based on data from 200 buildings $^{28}$. In a similar analysis, of 13 residential timber buildings in Germany and Austria alongside mineral comparators, the timber buildings had significantly lower embodied carbon (9-56\%) than their mineral counterparts ${ }^{29}$. A study in Nordic region, compared cradle-to-gate impacts for timber and mineral alternatives for four structures up to 21 stories: results were in the range $111-121 \mathrm{kgCO}_{2} \mathrm{e} / \mathrm{m}^{2}$ for mid-rise $\mathrm{RC}$ structures and $26-40 \mathrm{kgCO}_{2} \mathrm{e} / \mathrm{m}^{2}$ for timber ${ }^{30}$.

The Climate Change Committee (CCC) has recommended greater use of timber in buildings since at least as early as 2019. In its 2019 report "UK Housing Fit for the Future", the CCC recommended the implementation of new policies to support the reduction of the whole-life carbon impact of new homes, targeting embodied and sequestered carbon ${ }^{18}$. It found embodied carbon savings in the range of 220 to $260 \mathrm{kgCO}_{2} \mathrm{e} / \mathrm{m}^{2}$ (internal area) for the structures of apartment buildings in CLT compared to concrete, along with the result that a high-growth scenario for timber usage can reduce the embodied carbon of UK domestic building construction by $0.8-1.0 \mathrm{MtCO}_{2} \mathrm{e}$ annually by $2050^{18,24}$. This report showed that at an individual building level, the reduction in embodied emissions for substituting timber frame for masonry was approx. 20\%. However, a greater reduction ( $60 \%)$ was observed for CLT and concrete structures ${ }^{18,24}$. Additionally, it found that the level of carbon stored at a buildingscale was approximately 50\% higher for timber frame than masonry, or significantly higher for CLT ( 400\% the concrete structure) ${ }^{18,24}$. The residential sector construction scenario to 2050 showed that with moderate and high levels of timber usage deliver more GHG 
abatement than scenarios with low levels of timber usage. For high building rate and high timber usage scenarios, we estimate that high timber usage $(270,000$ new homes each year using timber frame and CLT systems) would result in (net) storage of sequestered carbon if around $3 \mathrm{MtCO}_{2} \mathrm{e}$ annually in 2050. This was $1.3 \mathrm{MtCO}_{2} \mathrm{e} /$ year higher than no growth in timber use scenario ${ }^{18,24}$. For embodied carbon, a moderate growth in timber usage $(135,000$ timber homes p.a.) leads to a 0.20 to $0.38 \mathrm{MtCO}_{2} \mathrm{e}$ saving/year by 2050 . The high growth scenarios lead to a reduction of 0.48 to $1.00 \mathrm{MtCO}_{2} \mathrm{e}$ /year. The lower end of these ranges assumes ambitious decarbonisation in the cement and masonry sectors ${ }^{18,24}$.

For non-residential sector, potential for increased use of wood in construction tremendous, offering up to 0.5 to $2.3 \mathrm{MtCO}_{2} \mathrm{e}$ stored sequestered carbon, under low and high timber growth $^{24}$. BioComposite Centre's analysis of the origin of timber and construction materials indicated that between 86 and 92\% of the GHG abatement achieved by increasing timber usage could be attributed to UK carbon accounts ${ }^{24}$.

Recent studies have shown a $27 \%$ to $77 \%$ reduction in upfront carbon emissions of timber structures $^{31}$. Engineered timber buildings are inherently draught-free due to the precision of the offsite manufacturing inherent in their construction process, permitting good thermal performance that provides it with higher operational efficiency in the long run ${ }^{32,33}$. It could act as a carbon capture and storage over the lifetime of the building, as building efficiency goes up and operation energy goes down ${ }^{32,33}$. Replacing concrete with timber in new construction could also repair the severe environmental degradation and depletion of deteriorating sand resources associated with the production of mineral-based building materials ${ }^{34}$. Fig 6 illustrates potential of bio-based construction materials as a replenishment mechanism in the nature.

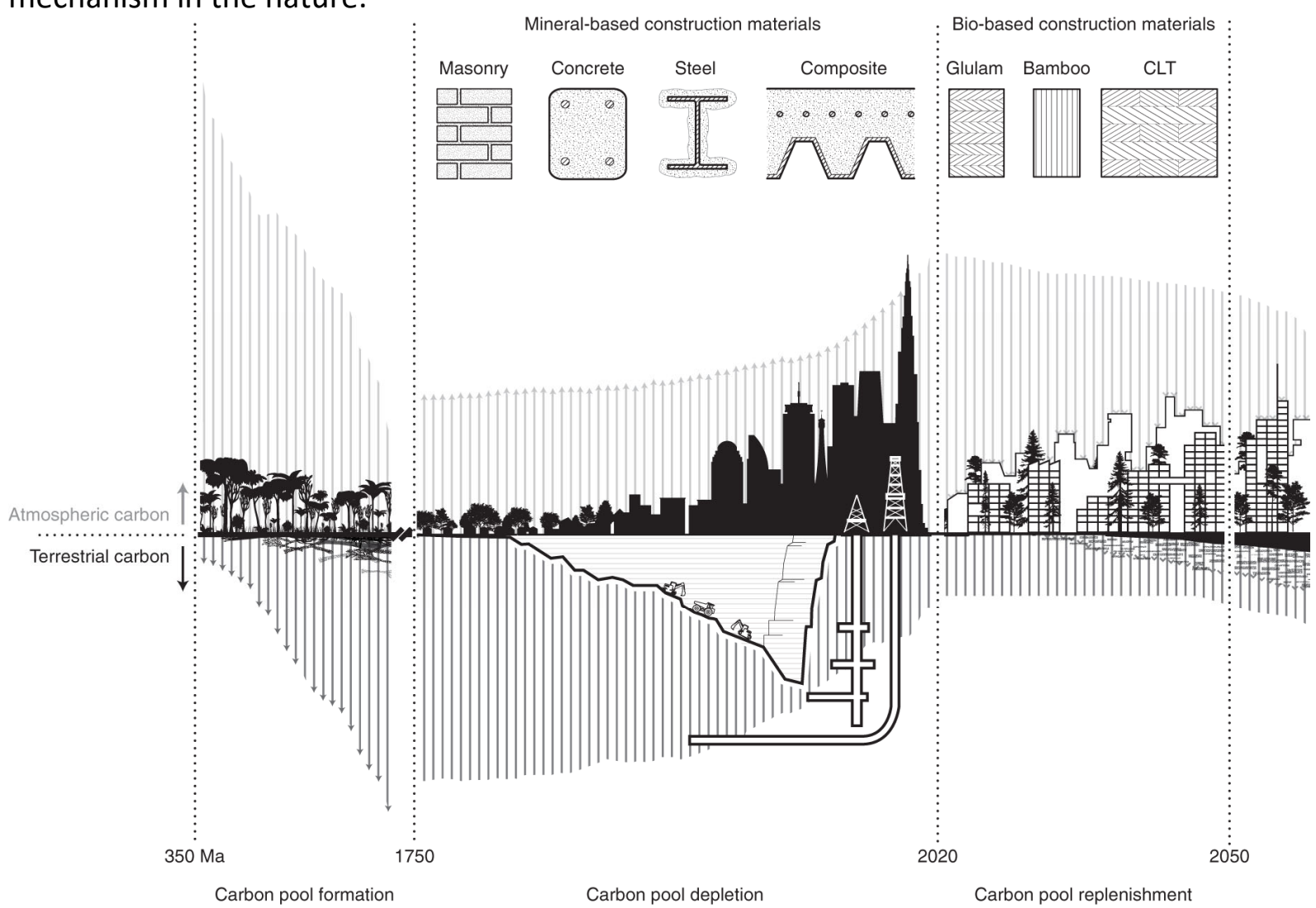

Fig 6. Nature-based building materials as a carbon sink. (Source: Nature Sustainability ${ }^{34}$ ) 
The use of plant-based insulating materials such as wood fibre insulation, could also allow for achieving required thermal performance (reducing operational emissions) while having lower embodied emissions than conventional insulating materials and storing sequestered carbon long-term ${ }^{35}$. Such materials can play a key role in achieving the UK Government's net zero ambitions, by enabling reductions in embodied and operational emissions while securely storing carbon in built structures. Recent studies have also shown that engineered timber structures can offer the required fire safety standards ${ }^{36-39}$ that provides opportunities for its large-scale applications.

Currently there is very low capacity in the UK for engineered timber and plant-based material manufacturing, though this is an area for value-adding. The National Housing Federation argues that to meet the current backlog of 4 million homes in England, 350,000 homes need to be built annually until $2031^{\prime}$. If these were to be built from CLT at $£ 240 / \mathrm{m}^{2}$, and $30-40 \%$ of the value in the CLT panels is in secondary processing (machining and fabrication) ${ }^{\mathrm{ii}}$, which our research aims to bring to the UK, up to $£ 2.5$ billion could be pumped into UK businesses annually. If timber was imported to UK (e.g. by sea from Sweden) and even primary processing of CLT took place in UK, $65-75 \%$ of the value of CLT would be retained in the UK. There is a real opportunity to establish a detailed manufacturing strategy to produce CLT and plantbased insulation materials for both the UK and the overseas markets post-Brexit ${ }^{40 .}$ Cropbased tree plantations can exist alongside forest conservation mechanisms to enable the building sector to move towards net zero. Such an approach is studied to be critical for transforming buildings as carbon sinks ${ }^{34,40}$. Besides, garnering evidence have shown that timber sourced from sustainable managed forests in Europe is not likely to pose deforestation risk $^{41}$. It could be used in the implementation of the UK Proposals for Carbon Capture Use and Storage (CCUS) for Net Zero for any proposed wood fibre insulation and engineered timber factories on Teesside ahead of COP26 $6^{42}$. The development of the Great North Forest when at maturity could provide a long-term sustainable source of timber with immediate managed replanting. Therefore, using trees as carbon sink and nature-based solution to carbon emissions in the built environment.

Due to its inherently prefabricated and modular nature, engineered timber is highly compatible with emerging digital design and fabrication methods which allow for a circular approach to the construction economy ${ }^{43}$. The UK government could establish an increasingly large and easily verifiable carbon sink in its built environment by supporting the design and construction of timber structures whose components can be easily reused in future construction. Integrating timber building elements as part of UK's Carbon Credit scheme could facilitate its industry-wide adoption ${ }^{44}$. Therefore, creating long-term carbon storage which is crucial for achieving the Government's net zero targets.

In addition to housing applications of engineered timber, there is also a tremendous opportunity for the construction of public buildings and schools using such nature-based materials. By 2024, the UK is expected to face a shortage of as many as 120,000 school places ${ }^{45}$. Building these schools using timber instead of steel and concrete could significantly reduce the embodied emissions associated with this construction, while securely storing large 
volumes of carbon in these structures, contributing towards meeting the Government's net zero targets.

Engineered timber offers an opportunity to help address the gender gap in the forestry and constructions sector too: All aspects of the forestry and construction industries have traditionally male cultures. ${ }^{\text {iii }}$ As an example, the engineering profession in the UK is only about $12 \%$ female. ${ }^{\text {iv }}$ The factory-basis and off-site prefabrication nature of engineered timber requires a different skill-set from traditional onsite construction. Improving access to these jobs to a wider group of people due to a fixed factory location and are less physically demanding, both for lifting and climate exposure may be more attractive to a broader demographic, including women, who currently make up only about $9 \%$ of construction workers ${ }^{v}$. This also helps with upskilling the labour force, reducing costly site time, and reducing injuries on-site.

The UK is legally committed to being zero carbon by 2050. As buildings become more energy efficient, the embodied energy of materials becomes dominant. Timber is the only large-scale construction material that can be grown. Forests remain the only globally available carbon capture and storage system. To fulfil our commitment to the environment, building with timber as a replacement for steel, concrete and masonry can put us on a path towards our carbon neutral goal2. To attain this, three policy changes are paramount.

- In building regulation, we must recognise that structure is not cladding

- Recent amendments in UK's fire regulations threaten to limit its application to residential and low-rise buildings. The tragedy of the Grenfell Tower fire triggered a review of building codes and fire safety regulations. Even though the use of engineered timber and primary structural materials did not form any part of the deficiencies identified in the report, the government proceeded to a ban of all combustible materials on external walls of high-rise residential buildings above 18 meters. However, the term "external walls" does not accurately represent the interactions between the different building components in high-rise buildings. Further clarifications and amendments are necessary to focus the ban of combustible materials on cladding panels only and make a clear distinction between cladding and primary structure. Avoiding such amendments has already had significant repercussions in the use of engineered timber as a structural material and inhibit growth in the engineered timber industry. Simultaneously, it would have a negative impact in addressing the shortage of housing and educational infrastructure in the UK in a cost-efficient and sustainable manner, in-line with its legally binding commitments to reduce greenhouse gas emissions. An amendment to the current ban will enable the definition of a clear model of risk ownership and

\footnotetext{
${ }^{2}$ https://www.theccc.org.uk/wp-content/uploads/2018/11/Biomass-in-a-low-carbon-economy-CCC-2018.pdf [accessed October 2020]
} 
render engineered timber part of a holistic design strategy and an evidencebased approach for fire-safe multi-family structures.

- In planning, we must consider whole-life carbon emissions

- Since the publication of the CCC's 2019 report, the Greater London Authority (GLA) has introduced draft guidance for whole-life carbon assessment of building projects, which will be required for projects referred to the mayor, but are recommended for all major buildings in the jurisdiction of the GLA. The final guidance will be issued in Summer $2021^{3}$. This is a promising first step. Our recommendation is that whole-life carbon assessments be required for all new buildings in the UK. Such a policy would allow for benchmarking of wholelife building performance which is critical for accurately assessing progress towards reducing the whole-life emissions of construction across the UK in line with decarbonisation targets.

- The Government could do more to encourage the greater adoption of timber in the construction of UK homes. France, for example, has mandated that all new public buildings must contain $50 \%$ natural materials (timber, hemp, straw) $)^{4}$. A similar policy for UK construction could create the demand volume and predictability needed to stimulate a domestic natural building materials industry in the UK.

We specifically recommend the Government take the following steps in its Planning for the Future planning reform:

- Starting immediately, require all proposed building projects to submit wholelife emissions assessments as part of the planning process, building on and leapfrogging London's proposed whole-life carbon assessment requirements.

- Based on the results of these whole-life emissions assessments, and using SCORS[SCORS], RIBA 2030[RIBA2030], Greater London Authority[GLA], and/or LETI targets [LETI], limit planning approval for high-carbon projects which yield low social benefits, such as luxury construction.

- Avoid demolition of existing serviceable structures wherever possible, favouring retrofit and in-situ reuse over new construction.

- Support designs, materials, and construction methods which enable low and zero whole-life emission construction. In particular, support the use of sustainably sourced timber instead of concrete and steel, where appropriate.

- In emissions policy, we must give timber buildings credit for long-term storage of CO2

\footnotetext{
3 "Whole Life-Cycle Carbon Assessments guidance ... - London.gov.uk." https://www.london.gov.uk/what-wedo/planning/implementing-london-plan/london-plan-guidance-and-spgs/whole-life-cycle-carbon-assessmentsguidance-consultation-draft. Accessed 5 May. 2021.

4 "France Wants All Public Buildings to Be Made of at Least 50\% Wood ...." 12 Feb. 2020, https://www.architecturaldigest.com/story/france-wants-all-public-buildings-to-be-made-of-at-least-50-woodby-2022. Accessed 6 May. 2021.
} 
O The UK government should buy the carbon stored in timber buildings, and establish a market upon which these can be traded. Buying them with grants would enable large and small stakeholders to take part, and the larger amount of carbon credits amassed by the government would be tradable at a large scale. Buildings typically have a lifetime of upwards of 70 years, and in a lowcarbon future, this could be a basis for a global buildings as material banks initiative. A trading system could be built on DEFRA's work in forest growth biomass credits.

Adopting these three policy changes would drive construction emissions down, and again make the UK a global leader in engineered timber construction, demonstrate the commitment to the Paris Agreement through renewable construction materials, and provide global leadership on emissions trading that recognises the mutual contributions of nature and construction with natural building materials to improving our atmosphere.

We have also been encouraged by the new 'sustainability' guidelines set out by ARB/RIBA that students ought to have covered at Part $1 / 2 / 3$ levels when seeking registration as architects. Education and upskilling has a huge role to play in decarbonising the built environment, and we also suggest that nature-based materials, particularly engineered timber and natural insulation materials, and designing with them, be given a more prominent space in the architecture curriculum. The Dept. of Architecture at the University of Cambridge is starting a new four-year undergraduate degree, The Design Tripos, which aims to address this, amongst other global challenges that need addressing through the confluence of materials, engineering and architecture via interdisciplinary design.

Our evidence synthesis has shown that the UK Government's current approach to reducing emissions from the building sector is geared towards minimising operating emissions ${ }^{45}$. However, to achieve the net zero targets by 2050, the built environment planning should adopt a "whole-life" emission approach to systematically estimate embodied emissions across the construction processes. It would enable data collection required to measure whole-life emissions in proposed new buildings, at the same time, pave an informed roadmap for future low-carbon building regulations. Requiring embodied carbon emissions reductions will result in specifiers choosing low-carbon materials and improving their design methods to achieve materially efficient designs. Requirements that new buildings comprise some proportion of natural materials could also stimulate the UK natural building materials industry. A 2019 report by the CCC outlined three strategies for incorporating embodied and sequestered carbon into building regulations ${ }^{46}$. These are: 1 ) "voluntary action \& Government leads by example through procurement", whereby the Government monitors and limits embodied carbon in the buildings it procures; 2) "whole-life elemental carbon intensity targets", whereby limits on embodied carbon are set for individual building products; and 3) "whole building life-cycle carbon intensity targets", whereby limits on embodied carbon are set for whole buildings ${ }^{46}$. 
Adaptive reuse and refurbishment typically have lower carbon impacts than new construction and should generally be considered before new construction. Timber, as a relatively lightweight structural material, offers an excellent opportunity for adaptive reuse of existing concrete buildings through the addition of stories built using timber without requiring significant modifications to foundations or structure ${ }^{47}$. The Government should introduce a policy whereby concrete buildings are never demolished, but rather are added to as needed using additional timber structure.

\section{References}

1. BEIS. 2019 UK Greenhouse Gas Emissions, Final Figures. 41 https://assets.publishing.service.gov.uk/government/uploads/system/uploads/attachment_data/file/957 887/2019_Final_greenhouse_gas_emissions_statistical_release.pdf (2021).

2. UK Government. Climate Change Act 2008. https://www.legislation.gov.uk/ukpga/2008/27/contents (2008).

3. IPCC. Global Warming of $1.5^{\circ} \mathrm{C}$ :An IPCC Special Report on the impacts of global warming of $1.5^{\circ} \mathrm{C}$ above preindustrial levels and related global greenhouse gas emission pathways, in the context of strengthening the global response to the threat of climate change, sustainable development, and efforts to eradicate poverty. https://www.ipcc.ch/site/assets/uploads/sites/2/2019/06/SR15_Full_Report_High_Res.pdf (2018).

4. UKGBC. Climate Change. UKGBC's vision for a sustainable built environment is one that mitigates and adapts to climate change. https://www.ukgbc.org/climate-change/ (2015).

5. CCC. The Sixth Carbon Budget: Buildings. https://www.theccc.org.uk/wp-content/uploads/2020/12/Sectorsummary-Buildings.pdf (2020).

6. BEIS. Energy Consumption in the UK. (2020).

7. UKGBC. Tackling embodied carbon in buildings. https://www.ukgbc.org/sites/default/files/Tackling\%20embodied\%20carbon\%20in\%20buildings.pdf (2014).

8. BEIS. Digest of UK Energy Statistics (DUKES): electricity. https://www.gov.uk/government/statistics/electricity-chapter-5-digest-of-united-kingdom-energystatistics-dukes (2020).

9. ARUP and GCB. Green Construction Board Low Carbon Routemap for the Built Environment. http://www.hwa.uk.com/site/wp-content/uploads/2020/10/CD-17.13-Low-Carbon-Routemap-for-theBuilt-Environment-Technical-Report-Green-Construction-Board-2015.pdf (2015).

10. DEFRA. Commission on Environmental Markets and Economic Performance. http://data.parliament.uk/DepositedPapers/Files/DEP2007-0076/DEP2007-0076.pdf (2007).

11. Carmichael, R. Behaviour change, public engagement and Net Zero: A report for the Committee on Climate Change. $\quad 81 \quad$ https://www.theccc.org.uk/wp-content/uploads/2019/10/Behaviour-change-publicengagement-and-Net-Zero-Imperial-College-London.pdf (2019).

12. Büchs, M. et al. Promoting low carbon behaviours through personalised information? Long-term evaluation of a carbon calculator interview. Energy Policy 120, 284-293 (2018).

13. IPCC. Buildings. In: Climate Change 2014: Mitigation of Climate Change. https://www.ipcc.ch/site/assets/uploads/2018/02/ipcc_wg3_ar5_chapter9.pdf (2018).

14. Cabinet Office UK. Behaviour Change and Energy Use. 35 https://assets.publishing.service.gov.uk/government/uploads/system/uploads/attachment_data/file/481 23/2135-behaviour-change-and-energy-use.pdf (2011).

15. House of Commons. Energy efficiency: building towards net zero. 83 https://publications.parliament.uk/pa/cm201719/cmselect/cmbeis/1730/1730.pdf (2019). 
16. Dosmukhambetova, D. The use of behavioural insights in promoting residential energy efficiency: an overview of available literature. (2020).

17. Taranu, V. \& Verbeeck, G. A closer look into the European Energy Performance Certificates under the lenses of behavioural insights-a comparative analysis. Energy Effic. 11, 1745-1761 (2018).

18. CCC. UK housing: fit for the future. https://www.theccc.org.uk/publication/uk-housing-fit-for-the-future/ (2019).

19. CCC. Reducing UK emissions - 2018 Progress Report to Parliament. https://www.theccc.org.uk/publication/reducing-uk-emissions-2018-progress-report-to-parliament/ (2018).

20. Hanmer, C., Shipworth, D., Shipworth, M. \& Johnson, C. Load shifting with smart home heating controls: Satisfying thermal comfort preferences. Eceee Summer Study Proceedings 1377-1386 https://www.eceee.org/library/conference_proceedings/eceee_Summer_Studies/2019/8-buildingstechnologies-and-systems-beyond-energy-efficiency/load-shifting-with-smart-home-heating-controlssatisfying-thermal-comfort-preferences/ (2019).

21. Parrish, B., Hielscher, S. \& Foxon, T. J. Consumers or users? The impact of user learning about smart hybrid heat pumps on policy trajectories for heat decarbonisation. Energy Policy 148, 112006 (2021).

22. Lin, H., Clavreul, J., Jeandaux, C., Crawley, J. \& Butnar, I. Environmental life cycle assessment of heating systems in the UK: Comparative assessment of hybrid heat pumps vs. condensing gas boilers. Energy Build. 240, 110865 (2021).

23. IEA. Global Status Report for Buildings and Construction. https://www.iea.org/reports/global-status-reportfor-buildings-and-construction-2019 (2019).

24. Spear, M., Hill, C., Norton, A., \& Price, C. Wood in Construction in the UK: An Analysis of Carbon Abatement Potential (BioComposites Centre). https://www.theccc.org.uk/publication/wood-in-construction-in-the-ukan-analysis-of-carbon-abatement-potential-biocomposites-centre/ (2019).

25. Hart, J., D’Amico, B. \& Pomponi, F. Whole-life embodied carbon in multistory buildings: Steel, concrete and timber structures. J. Ind. Ecol. 25, 403-418 (2021).

26. СтBUH. Tall Buildings In Numbers - Tall Timber. Counc. Tall Build. Urban Habitat J. 47-49 (2017).

27. Teshnizi, Z., Pilon, A., Storey, S., Lopez, D. \& Froese, T. M. Lessons Learned from Life Cycle Assessment and Life Cycle Costing of Two Residential Towers at the University of British Columbia. Procedia CIRP 69, 172177 (2018).

28. De Wolf, C. et al. Material quantities and embodied carbon dioxide in structures. Proc. Inst. Civ. Eng. - Eng. Sustain. 169, 150-161 (2016).

29. Hafner, A. \& Schäfer, S. Comparative LCA study of different timber and mineral buildings and calculation method for substitution factors on building level. J. Clean. Prod. 167, 630-642 (2017).

30. Skullestad, J. L., Bohne, R. A. \& Lohne, J. High-rise Timber Buildings as a Climate Change Mitigation Measure - A Comparative LCA of Structural System Alternatives. Energy Procedia 96, 112-123 (2016).

31. Malmqvist, T. et al. Design and construction strategies for reducing embodied impacts from buildings - Case study analysis. Energy Build. 166, 35-47 (2018).

32. Hertwich, E. G. et al. Material efficiency strategies to reducing greenhouse gas emissions associated with buildings, vehicles, and electronics-a review. Environ. Res. Lett. 14, 043004 (2019).

33. Herren, N. et al. Environmental Impact of Buildings-What Matters? Environ. Sci. Technol. 49, 9832-9841 (2015).

34. Churkina, G. et al. Buildings as a global carbon sink. Nat. Sustain. 3, 269-276 (2020).

35. Kumar, D., Alam, M., Zou, P. X. W., Sanjayan, J. G. \& Memon, R. A. Comparative analysis of building insulation material properties and performance. Renew. Sustain. Energy Rev. 131, 110038 (2020).

36. Bartlett, A. et al. Needs for total fire engineering of mass timber buildings. in (2016). 
37. Östman, B., Brandon, D. \& Frantzich, H. Fire safety engineering in timber buildings. Fire Saf. J. 91, 11-20 (2017).

38. Barber, D. Fire Safety of Mass timber Buildings with CLT in USA. Wood Fiber Sci. 50, 83-95 (2018).

39. Frangi, A., Fontana, M. \& Knobloch, M. Fire Design Concepts for Tall Timber Buildings. Struct. Eng. Int. 18, 148-155 (2008).

40. The Forests Dialogue. Climate Benefits and Challenges Related to "Mass Timber" Construction: From Frame to Forest.

https://theforestsdialogue.org/sites/default/files/2021_29junebackgroundpaperclimate_interactive.pdf (2021).

41. Ramage, M. H. et al. The wood from the trees: The use of timber in construction. Renew. Sustain. Energy Rev. 68, 333-359 (2017).

42. NZT. Net Zero Teesside. https://www.netzeroteesside.co.uk (2021).

43. Wood for Good. Encompassing the circular economy. https://woodforgood.com/news-andviews/2020/07/29/encompassing-the-circular-economy/ (2021).

44. Financial TImes. UK carbon trading system to launch in May. Financial Times (2021).

45. UK Government. The Future Homes Standard: changes to Part $L$ and Part $F$ of the Building Regulations for new dwellings. https://www.gov.uk/government/consultations/the-future-homes-standard-changes-topart-l-and-part-f-of-the-building-regulations-for-new-dwellings (2019).

46. CCC. Options for incorporating embodied and sequestered carbon into the building standards framework (AECOM). https://www.theccc.org.uk/publication/options-for-incorporating-embodied-and-sequesteredcarbon-into-the-building-standards-framework-aecom/ (2019).

47. Ramage, M., Foster, R., Smith, S., Flanagan, K. \& Bakker, R. Super Tall Timber: design research for the next generation of natural structure. J. Archit. 22, 104-122 (2017).

\footnotetext{
i England short of four million homes, <https://www.housing.org.uk/press/press-releases/england-short-of-fourmillion-homes/> (May 18 2018).

ii Smith, S. Cross Laminated Timber. (Smith and Wallwork Engineers, Cambridge, UK, 2018).

iii Shamil George Naoum, Ph.D.; Jennifer Harris; Joseph Rizzuto, Ph.D., CEng.; and Charles Egbu, Ph.D. (2020) Gender in the Construction Industry: Literature Review and Comparative Survey of Men's and Women's Perceptions in UK Construction Consultancies. Journal of Management in Engineering ASCE [https://doi.org/10.1061/(ASCE)ME.1943-5479.0000731]

iv The Women's Engineering Society statistics, [https://www.wes.org.uk/content/wess]

${ }^{v}$ Amaratunga, Dilanthi, Haigh, Richard, Shanmugam, M., Lee, A. J. and Elvitigala, Gayani (2006) Construction industry and women: a review of the barriers. In: 3rd International SCRI Research Symposium, 3-4th April 2006, Delft University, Netherlands.
} 